International Journal of Social Science and Economic Research

ISSN: 2455-8834

Volume:05, Issue:11 "November 2020"

\title{
NEED OF EMERGENCY MEASURES IN MODEL TENANCY ACT
}

\author{
Mandeep Kumar \\ Research Scholars, Department of Laws, Panjab University, Chandigarh \\ DOI: 10.46609/IJSSER.2020.v05i11.027 URL: https://doi.org/10.46609/IJSSER.2020.v05i11.027
}

Outbreak of Covid-19 Pandemic has shattered the established socio-economic principles. It has not only created a fear of sickness and untimely death but has also raised a sense of economic insecurity. Lockdown, social distancing, restricted movement, etc. have halted the dynamic engine of economic growth ${ }^{1}$. It has affected all segments of the economy like production, manufacturing, trading, services, transportation etc. The businessmen, employees, workers, etc everybody has felt the heat of adverse affects caused due to Covid-19 Pandemic.

In a common parlance, everybody is expecting consistent income along with periodical increments to the same. Such consistency of the income is a main factor to feel social security. However, everybody has suffered a substantial loss of business/income due to this ongoing situation of Covid-19 Pandemic. However, in case of tenancies, its affect is unequal. The businessmen carrying on their business from rental premises, are worst suffered. On the one hand, their income has steeply fallen down but on the other hand their liability to pay rent of the premises as well as to pay wages to the workers has been remained intact. Though, the negotiations with the workers to cut the wages are little bit easy but their requests to reduce the rate of rent during ongoing situation are not being entertained by most of the landlords ${ }^{2}$. In several cases, the landlords are postponing the part payment of rents to some future dates but are not accepting the requests to waive off the rent partly or fully during currency of ongoing situation. Despite of such refusal, most of the traders/businessmen are not in the position to immediately stop their business due to fixed investment already made. Therefore, they are constrained to continue their business and to bear the periodical expenditure in the shape of rents, wages and other running costs like electricity, water, etc. expenses. It has been observed that a number of such businessmen are in catch-22 situation to continue their business at the cost of net loss and erosion of their investment. It is apprehended that many of such businessmen would ultimately come on the road after suffering continuous loss for several months as the Covid-19 situation would be continuous for several months. Such failure of businesses has not only

\footnotetext{
${ }^{1}$ Effect of COVID-19 on Economy in India: Some Reflections for Policy and Programme by Monika Chaudhary , P. R. Sodani and Shankar Das (Journal of Health Management)

${ }^{2}$ Delhi landlords face off against students over unpaid rent: Will Kejriwal's promise of paying rent actually happen? :By Prajanma Das, Published on $29^{\text {th }}$ April,2020 in Edex Live (The New Indian Express)
} 


\section{International Journal of Social Science and Economic Research}

ISSN: $2455-8834$

Volume:05, Issue:11 "November 2020"

affected the families of such businessmen and traders but also the families of their workers. The banks have granted the moratorium ${ }^{3}$, the Governments have offered several concessions/assistances to ensure the survival of businesses and trades ${ }^{4}$. However, the landlord of such rented premises is not granting any substantial relief to their tenants to ensure their survival being not having any bounden duty. Same is also happening in the case of rental residential premises. The tenants of such residential premises are facing income/salary loss and are struggling for their survival waiting for end of Covid-19 Pandemic due to development of some vaccine or otherwise.

In this struggling period of the society particularly tenants, it is the moral and ethical duty of the landlords also to give up their income as per their capacity. It is understandable that everybody creates his daily expenses as per his re-occurring consistent income and it is not easy to make a cut in expenses abruptly. However, that is the case with the both i.e. tenants as well as landlords. As tenants are cutting their expenses to bare minimum, the landlords also need to cut their expenses to a reasonable extent. Otherwise also, the daily expenses of the life have been drastically come down during the ongoing pandemic situation due to bare minimum social and domestic activities under the social distancing precautions particularly lock-down. Therefore, the landlords should have no right to expect and claim consistent regular rental income under such emergent situation.

Nobody is bound to go by his moral and ethical duty in the existing legal framework so are landlords. Therefore, it is essential to make it a legal duty to enforce it in the larger interest of the public. Under such facts and circumstances, the relevancy of rent control laws is again required to be recognized. The rent control laws were introduced in the various States/Provinces of India on the outbreak of First World War ${ }^{5}$. Again on the outbreak of Second World War, the rent control laws were introduced as a short term measure to restrict the rates of rent as well as eviction of tenants ${ }^{6}$. However, such rent control laws had been continued in the independent India as social welfare legislation in the name of protection to the poor tenants. However, the continuation of rent control laws in the normal situation had become counter-productive to the tenants also while such laws were already adversely affecting the landlords since its inception. Therefore, a sense has been developed that the rent control laws are not in the interest of any section of the Society. Therefore, a need has been felt to take a shift from controlling system to

${ }^{3}$ COVID-19-Regulatory Package granted by Reserve Bank of India vide letter no.RBI/2019-20/186, DOR.No.BP.BC.47/21.04.048/2019-20 dated March 27, 2020

${ }^{4}$ Covid-19 Relief for MSME Sector, Ministry of Micro, Small and Medium Enterprises, Government of India.

${ }^{5}$ The Bombay Rent (War Restrictions) Act, 1918, the Calcutta Rent Control Act, 1920 and the Rangoon Rent Act, 1920

${ }^{6}$ New Delhi House Rent Control Order came into existence in 1939 followed by the Punjab, Mysore and Madras Rent Control Orders in 1941 


\section{International Journal of Social Science and Economic Research}

ISSN: $2455-8834$

Volume:05, Issue:11 "November 2020"

regulatory system for tenancy ${ }^{7}$. A Model Tenancy Act was circulated by the Govt. of India in 1992 and a number of States have adopted the same with certain modifications though rent control laws are also still prevailing to some extent. In such regulatory laws, a provision was introduced to fix a reasonable rate of rent and its periodical increase on the basis of consumer price index, wholesale price index or any other such factor. However, the eviction of the tenant was still restricted even on the expiry of the agreed term of tenancy.

In $21^{\text {st }}$ century, a need was felt to increase the housing stock in the urban areas to meet the requirement of rapid urbanization. It has also been established that most of the working class including migrants prefer the rental housing due to non-permanent job engagement and low investment/parking of money in rental housing. The Govt. of India has also circulated the Draft of National Urban Rental Housing Policy in October, 2015. In the said policy, it was observed that the rent control laws indirectly discriminate against the small owners/under privileged residents of urban areas. It was also observed that at the low rental yields as compared to prices of real estates, there is only a limited participation of the investors in the rental housing markets. One of the main factor preventing investments in rental housing was recognized as rent control laws. It was also observed that the rent control laws have resulted in substantial reduction in residential construction for rent and that all new residential developments are primarily made for sales. State Governments have been suggested in the said Policy to repeal/amend the existing rent control legislations and to adopt the Draft Model Tenancy Act, 2015.

The Draft Model Tenancy Act, 2015 as referred in the National Urban Rental Housing Policy, has passed through the several stages and has now finally been circulated to State Governments to give the comments/suggestions on the Draft Model Tenancy Act (now it is called as Model Tenancy Act, 2019). Concept of statutory tenants has been abolished in the Model Tenancy Act and by over- possessiveness to the concept of free market, the sanctity of the terms and conditions of the tenancy agreement have been fully recognized regarding the rates of rent as well as eviction of tenants on expiry of the lease term

It is already explained that in some of the disastrous events like outbreak of Covid-19, the income of the businessmen, traders, workers is adversely affected. Therefore, in a case where disastrous event affects the economy of the State and the income of the people substantially falls down, it is not appropriate to ensure the consistent rental income for the landlords. Such disastrous event requires forbearance by all sections of the Society. In fact, such circumstances demand donations and otherwise help from the capable sections of the society. The tenancy is a 'completed conveyance" ${ }^{8}$ and tenancy agreement is an 'executed contract' and not an 'executor

\footnotetext{
${ }^{7}$ Rent Matters on Trial by Dr. D.N. Jauhar, Published by Punjab Law Reporter (1998)

${ }^{8}$ Raja Dhruv Dev Chand Vs. Raja Harmohinder Singh \& Anr, AIR 1968 SC 1024
} 


\section{International Journal of Social Science and Economic Research}

ISSN: $2455-8834$

Volume:05, Issue:11 "November 2020"

contract' ${ }^{\prime}$. Once the lessee obtains possession from the lessor i.e. completed the conveyance, the lease agreement becomes an executed contract and the lessee becomes bound to pay the agreed consideration during the duration of the lease as per terms of the agreement and it hardly matters that rents have fallen in the meanwhile. Therefore, the tenants, whether under contractual or statutory tenancy, cannot seek waiver or suspension of rent pleading implied force majeure condition. The Hon'ble Delhi High Court has held that temporary non-use of premises due to the lockdown which was announced due to the COVID-19 outbreak cannot be construed as rendering the lease void under Section 108(B)(e) ${ }^{10}$ of the TPA and therefore, the tenant cannot also avoid payment of rent in view of Section 108(B)(1) ${ }^{11}$. It has also been observed that in the absence of a contractual stipulation, the tenant may generally seek suspension of rent by invoking the equitable jurisdiction of the Court due to temporary non-use of the premises and in such cases the question as to whether the suspension of rent ought to be granted or not would depend upon the facts and circumstances of each case. ${ }^{12}$

Therefore, the tenants should not be left on the mercy of the landlords on occurrence of any such event. Non-recognition of such aspects in the relevant law would not cause only injustice to the families of the tenants as well as other persons who dependent on such tenants for their income but undue enrichment of landlords. Therefore, there is a need of such provisions in the tenancy law which can appropriately regulate the landlord tenant relationship during such emergency period.

Taking the experience from situation arisen due to Covid-19 outbreak, a set of emergent measures needs to be made available for all times to come which can be invoked on emergence of any such disastrous event, Therefore, such set of legal framework should be introduced as an integral part of the Model Tenancy Act, 2019. However, in view of the old experience with the rent control laws, it should be provided that the enforcement of such legal framework would require the ex-post facto approval of the concerned legislature in its first session after such enforcement and that any such order of enforcement of such legal framework should not be continuous for a period of more than one year. Any extension beyond that should require the approval of legislature on year to year basis. It should also be provided that the application of such legal framework should not be mechanically enforced on all of the urban areas of the

\footnotetext{
${ }^{9}$ Hotel Leela Venture Ltd. Vs Airports Authority of India, 2016 (160) DRJ 186 Del. (DB)

${ }^{10}$ Section 108(B)(e) in The Transfer of Property Act, 1882: if by fire, tempest or flood, or violence of an army or of a mob, or other irresistible force, any material part of the property be wholly destroyed or rendered substantially and permanently unfit for the purposes for which it was let, the lease shall, at the option of the lessee, be void:

Provided that, if the injury be occasioned by the wrongful act or default of the lessee, he shall not be entitled to avail himself of the benefit of this provision.

${ }^{11}$ (1) the lessee is bound to pay or tender, at the proper time and place, the premium or rent to the lessor or his agent in this behalf.

${ }^{12}$ Ramanand \& Ors vs Dr Girish Soni \& Anr, decided on 21 May, 2020 Del.
} 
concerned State and it should be enforced only on each urban areas basis wherever its need would be felt for the reasons to be recorded in writing.

In view of above, the Govt. of India should take the cognizance of peculiar experiences of the ongoing Covid-19 pandemic situation and provide appropriate emergency measures in the Model Tenancy Act to check and balance the interests of landlords and tenants in such peculiar situations. 